\title{
Opportunity Zones-The Symbiosis of Tax Incentives and Community Development
}

\section{Rachel Raskin, CPA}

New York City College of Technology

USA

Sharon Brickman, CPA

Borough of Manhattan Community College

USA

\section{ABSTRACT}

U.S. lawmakers have created one of the greatest tax-avoidance opportunities in American history, while simultaneously serving underperforming American cities and neighbourhood's (Bertoni 2018). Subchapter $Z$ of The Investing in Opportunity Act ("The Act"), as part of the 2017 Tax Cuts and Jobs Act (TCJA), amended the Internal Revenue Code to provide major tax incentives for investments in designated "Opportunity Zones". The tax incentives act as subsidies by allowing investors to defer the recognition of capital gains from the sale of appreciated assets if they are timely reinvested in opportunity zones (Bertoni 2018). According to the Economic Innovation Group (2018), there is approximately $\$ 6.1$ trillion of unrealized capital gains in stocks and mutual funds in the U.S. economy. Under the direction of sophisticated investors, this capital can be channelled to revitalize depressed communities and create jobs, infrastructure, and other economic opportunities. In a press release, the Department of Treasury (2018) revealed that it anticipates $\$ 100$ billion in private funds will be invested in opportunity zones over the next eight years. If the intention of the act comes to fruition, capital gains that investors realize from selling previous investments will be used to fuel growth in economically depressed areas.

\section{KEYWORDS: Investing Opportunity Act, 2017 Tax Cuts and Jobs Act, Qualified Opportunity Zone, Qualified Opportunity Fund, Tax Deferral, Permanent Tax Avoidance, Qualified Opportunity Zone Business}

\section{Designation of a Qualified Opportunity Zone}

$\S 1400 Z-1$ of "The Act" gives power to state governors to select population census tracts in low-income communities and submit selections to the Department of the Treasury to be certified as Qualified Opportunity Zones (QOZ). Each state may designate no more than $25 \%$ of their total low-income communities as QOZs. If the state has less than 100 low-income communities, it may still designate a total of 25 QOZs. Further, a population census tract that is not a low-income community, but is contiguous to a lowincome community, may also be designated as a QOZ provided that the median family income of this tract is not greater than $125 \%$ of the median family income of the community with which it is contiguous.

Additionally, such designations may not exceed 5\% of the total QOZs in the State. Once a designation is made, it is in effect for 10 years. According to the Internal Revenue Bulletin 2018-48 (IRS 2018), nearly 9,000 opportunity zones have been designated thus far.

\section{Conditions of the Tax Deferral}

$\S 1400 Z-2$ of the Internal Revenue Code allows for gains from the sale or exchange of property with an unrelated party to be tax-deferred under the following parameters:

- The investor makes an election to invest that gain in a Qualified Opportunity Fund (QOF) within 180 days of the sale or exchange.
- The gain reinvested must be capital in character. Thus, gains from the sale of ordinary income property (assets considered inventory to the taxpayer) and Sections 1245 and 1250 depreciation recapture are taxed as ordinary income and not eligible for favorable tax treatment upon reinvestment in a QOZ.

- Per the IRS Tax Tip 2018-191, taxpayers make deferral elections on Form 8949 and attach the form to their federal income tax returns in the same year that the capital gain would have been recognized (IRS 2018).

- An election is made before December 31, 2026.

- A previous election concerning the sale or exchange cannot have been made.

- There is no dollar value limitation on the deferred gain.

- The deferred gain must be ultimately recognized at the time of the sale of the QOF investment or by December 31, 2026, whichever is earlier.

\section{Permanent Tax Avoidance}

The next leg of $\S 1400 Z-2$ enables investors to realize capital gains from the sale of appreciated investments if invested into QOFs without any (or with little) gain recognition for federal income tax purposes. The extent of the savings is determined by the length of time the investment is held in the QOF. More specifically, when a 


\section{International Journal of Business and Applied Social Science (IJBASS)}

E-ISSN: 2469-6501

VOL: 6, ISSUE: 4

April/2020

DOI: $10.33642 / \mathrm{jJbass.v6n4p8}$

CPER

\section{(C) Center for Promoting Education and Research (CPER) USA}

capital gain is reinvested into a QOF, the initial basis in the investment is zero. If the investment is held in the fund for 5 years, then the initial basis of the reinvested capital gain will be adjusted to $10 \%$ of the reinvested capital gain. If the investment is held in the fund for 7 years, then the initial basis will be adjusted to $15 \%$ of the reinvested capital gain. Holding the investment for 5 or 7 years would reduce the tax liability on the deferred gain by $10 \%$ or $15 \%$, respectively. The greatest tax savings can be attained by holding the investment in the fund for 10 years.

At this point, the basis of the investment will be adjusted to the fair market value on the date of the sale, thus reducing both the capital gain the tax liability to zero. The IRS released proposed regulations (REG-115420-18) and a revenue ruling (Rev. Rul. 2018-29) in October 2018, expanding and clarifying several issues regarding opportunity zone investments. The proposed regulations state that QOF investments can be rolled over to other QOZ investments but it is uncertain whether the holding period of the old investment will carry over to the new investment. The proposed regulations also clarify that deferral of capital gains is available to individuals, $\mathrm{C}$ corporations (including regulated investment companies (RICs), real estate investment trusts (REITs)), partnerships, and certain other pass-through entities.

\section{An Illustrative Example}

Suppose that on January 1, 2019, an investor sells stock with a basis of $\$ 1$ million for $\$ 3$ million, realizing a capital gain of $\$ 2$ million. Instead of recognizing that gain in that tax year, the investor can reinvest the $\$ 2$ million gain in a QOF within 180 days of the sale, and be able to defer recognition of the gain until either the sale of the QOF investment or December 31, 2026, whichever is earlier.

Suppose the investor reinvested the $\$ 2$ million capital gain into a QOF on June 30, 2019. The initial basis in the QOF investment will be zero. If the investor holds the opportunity fund investment for 5 years, the basis of the reinvested capital gain will be adjusted to $10 \%$ of the 2 million, or $\$ 200,000$. If the investor holds the investment for another 2 years, for a total of 7 years, the basis of the reinvested gain will be adjusted by another $5 \%$ of the $\$ 2$ million, bringing the basis to $\$ 300,000$. Either upon sale or by December 31, 2026, whichever is earlier, the lesser of the amount realized/fair market value less basis or the deferred gain less basis must be recognized.

Assuming the investor still holds the $\$ 2$ million QOF Investment on December 31, 2026, and the investment had appreciated, he would recognize a capital gain of $\$ 1.7$ million ( $\$ 2$ million deferred gain minus $\$ 300,000$ basis) at that point. Further, the investor's basis in the investment is increased by the amount of gain recognized, bringing the basis to $\$ 2$ million $(\$ 300,000+\$ 1.7$ million). If the investment is sold before the 10- year holding period, which is June 30, 2029 , in our example, a capital gain would be recognized based on the amount realized less the $\$ 2$ million stepped-up bases. However, if the investment is sold beyond the 10-year holding period, the sale would not result in taxable gains at all, since the basis of the investment increases to its fair market value on the date of sale when held to that extent.

So, if after a 10-year holding period, the investor sells the investment in the QOF for \$6 million, the basis in the investment increases to $\$ 6$ million and no gain is recognized upon sale.

To sum up the tax savings of this example, $\$ 300,000$ ( $15 \%$ of $\$ 2$ million) is excluded from tax stemming from the initial reinvested capital gain, and $\$ 4$ million is excluded from tax stemming from the appreciation of the QOF investment.

It is important to note, as is apparent in the above example, that only reinvested capital gains in a QOF are eligible for favorable tax treatment rather than the total sales proceeds. If an amount that is greater than a capital gain is invested in a QOF, then it is assumed that the taxpayer has two separate investments in the fund.

Favorable tax treatment will be applied only to the investment that represents the deferred capital gain. If we revert to the above example, and the investor would choose to invest his total proceeds of $\$ 3$ million instead of just his capital gain of $\$ 2$ million, then the investor is considered to have two investments. The $\$ 2$ million reinvestment of capital gain will be treated as explained above. The additional $\$ 1$ million investment, which represents his original basis in his original investment, will not be eligible for the favorable tax treatment under $\S 1400 \mathrm{Z}-2$. 


\section{International Journal of Business and Applied Social Science (IJBASS)}

E-ISSN: 2469-6501

VOL: 6, ISSUE: 4

April/2020

DOI: 10.33642/fjbass.v6n4p8

https://iibassnet.com/

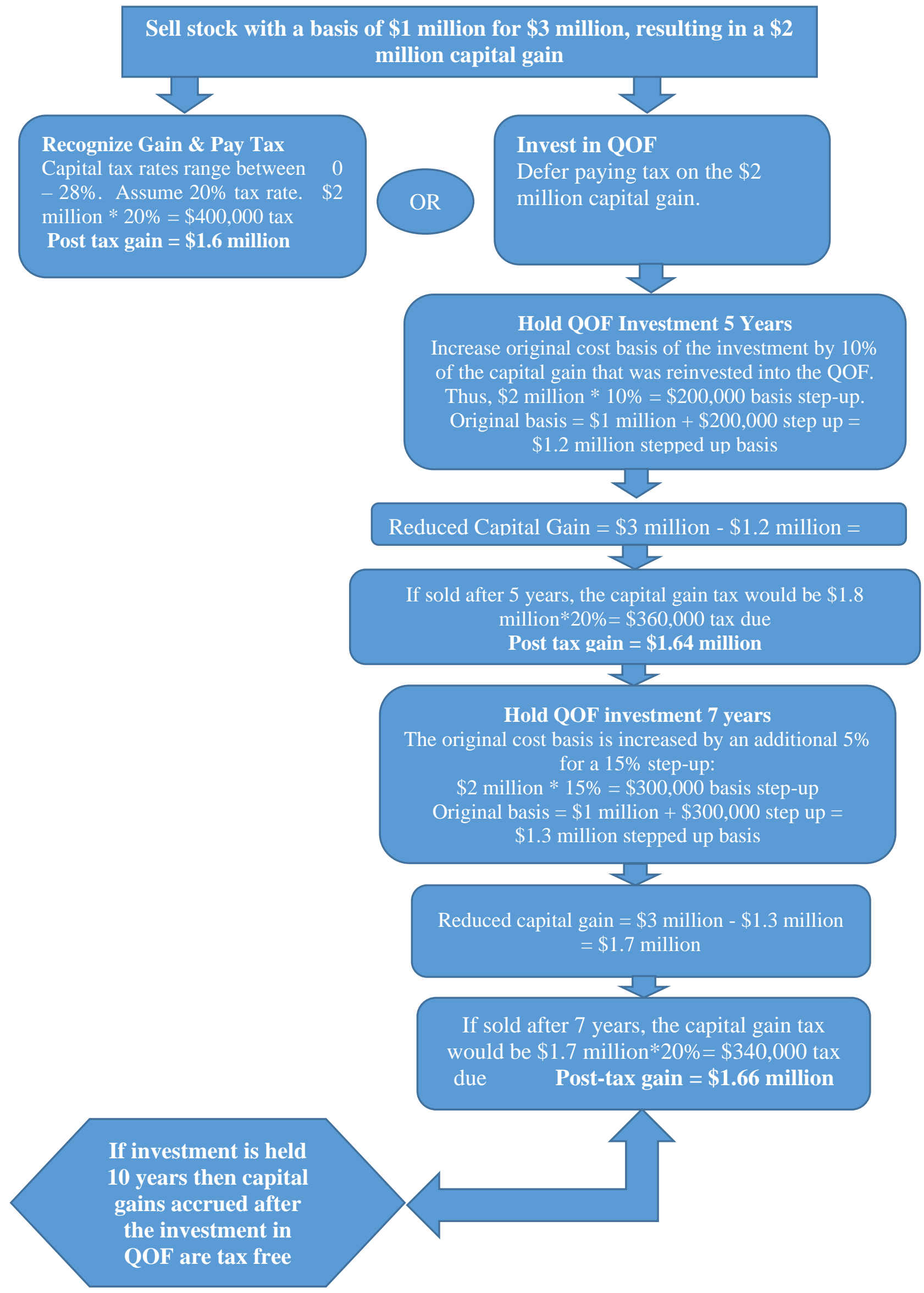




\section{Qualified Opportunity Funds}

$\S 1400 \mathrm{Z}-2$ allows investors to invest in opportunity zones by reinvesting capital gains realized from other assets to QOFs, which are corporations or partnerships formed under the law of the U.S., District of Columbia or a U.S. possession that make an election to be treated as a QOF. A QOF can also be a limited liability company that elects to be taxed as a corporation or has two or more members and is a partnership for federal income tax purposes. A new form 8996, released in December 2018 as a draft, maybe filed to self-certify as a QOF provided the specified requirements are met.

QOFs must hold at least $90 \%$ of their tangible assets in Qualified Opportunity Zone (QOZ) property, calculated by averaging the percentage of QOZ property held in the fund on the last day of the first 6-month period of the fund's taxable year and the last day of fund's taxable year. A QOF can directly own QOZ property or it can hold stock or partnership interest in a QOZ trade or business (including preferred stock or partnership interests with special allocations) in which substantially all assets are QOZ business property. The proposed regulations define substantially all, as having at least $70 \%$ of tangible property within an opportunity zone. The 70 percent requirement will give QOFs an incentive to invest in a QOZ business rather than owning qualified opportunity zone business property directly as it allows a QOF to receive tax benefits while investing only 63 percent $(90 \%$ in the QOZ business* $70 \%$ of the business' property) of its assets within a qualified opportunity zone, thereby propelling investment in lower-scale entities.

\section{Qualified Opportunity Zone Business}

QOZ business property must be purchased from an unrelated party after December 31, 2017, and per section 1400Z-2, be of original use in the QOZ business/QOF or the QOF must make substantial improvements to the property. The proposed regulations and Revenue Ruling 2018-29 offer further clarity with regards to QOZ business property, highlighted below:

- To qualify as QOZ business property, the QOF must place the property into service or substantially improve the property by doubling its adjusted tax basis throughout 30 months post-acquisition. In the case of real property, original use can mean constructing a new building or substantially improving an existing building. For instance, a QOF may purchase an old building for $\$ 600,000$ then spend another $\$ 600,000$ to knock it down and construct a new building, doubling the adjusted basis of the property to $\$ 1,200,000$. Revenue Ruling 201829 states that the original use requirement does not apply to land, and the cost of land on which such a building stands is excluded when calculating substantial improvement. This reduces the expenditures required to double the adjusted basis of the property and encourages the rehabilitation of vacant buildings in QOZs. Thus, the basis of land does not have to be increased if the building on the acquired land is substantially improved. However, it is still unclear whether the land on which a building stands is a qualifying asset for purposes of the 90\% Asset Test for a $Q O F$.

- Given that QOZ property must be purchased after December 31, 2017, a QOZ business cannot simply place in service $Q O Z$ property that it already owns. However, it is unclear whether vacant land owned by the QOF before the cut-off date would be considered QOZ property.

- The proposed regulations assert that if a QOF invests in a QOZ business, 50\% of the business's gross income must be from the active conduct of a business in a $Q O Z$ and a substantial portion of QOZ business' intangible property must be used in the active conduct of a trade or business in the QOZ.

- A QOZ business is subject to the requirements of section $1397 C(b)(8)$, Enterprise Zone Facility Bonds (IRS 1996); that less than 5 percent of the aggregate adjusted basis of the entity is attributable to nonqualified financial property (debt, stock, partnership interests, options, futures contracts, forward contracts, warrants, notional principal contracts, annuities, and other similar property specified in regulations).

- Given that business ventures may take a significant amount of time to cultivate, there was a concern regarding the six-month deadline provided under section 1400Z-2(d)(1) to invest in qualifying assets The proposed regulations offer a safe harbor that allows QOZ businesses to apply the definition of working capital provided in Section 1397C(e)(1) to property held by the business for a period of up to 31 months. The safe harbor would apply as long as there is a written plan that identifies the financial property as property held for the acquisition, construction or substantial improvement of tangible property in the opportunity zone and there is written schedule consistent with the ordinary business operations of the business that the property will be used within 31months, and the business substantially complies with the schedule. The investment earnings on these cash or cash equivalents are not considered in the requirement that at least 50 percent of the qualified 
opportunity business's gross income be from active business.

\section{Deferred Gain Tax Characteristics}

The proposed regulations clarify that deferred gains preserve their tax attributes through the deferral period. That is, if short-term gains are reinvested into a QOZ they will remain characterized as such and not be considered longterm gains when they are included in income, even when the QOZ investment is held for more than one year.

Throughout the deferral period, the character of capital gain as short-term, long-term Section 1231, Section 1250 , etc. is maintained and taxed accordingly after the deferral period.

\section{Updated Partnership Considerations}

The proposed regulations provide that unless a partnership reinvests the gain from an asset sale into a QOZ investment at the entity level, the gain can flow through to the partners allowing partners to reinvest their share of the gain. If the gain flows through to the partners, then the partners will have 180 days from the last day of the partnership's taxable year to reinvest the gain in a QOZ.

However, if the partnership reinvests the gain, then the allowable period would be 180 days from the date of the sale. The proposed regulations also permit entities treated as partnerships for federal income tax purposes, or LLCs, to become QOFs and allow for pre-existing entities to selfcertify as QOFs if they meet the requirements of section 1400Z-2(d).

\section{Extended Designations}

Section 1400Z-1 states that the designation of an area as an Opportunity Zone lasts for 10 years. The proposed regulations offer guidance as to how an investment in a QOZ will be treated when its designation expires. The proposed regulations state that even if an opportunity zone's designation expires, the tax benefits will apply to investments that remain in the zone's funds through 2047. Further, the guidelines state that gains can be transferred between opportunity funds until the December 31, 2026 cutoff when capital gains tax must be recognized.

\section{Low Income Housing Tax Credit vs. Opportunity Zone Tax Incentives}

As part of the Tax Reform Act of 1986 (P.L. 99-514), Congress enacted the IRC $\$ 42$ Low Income Housing Tax Credit (LIHTC) Program to encourage new construction and rehabilitation of existing buildings as low-income rental housing for households with income at or below specified income levels. Developers receive credits which are calculated as a percentage of their construction costs, allocation of low-income units (LIHTC projects can be a combination of low-income units and market-rate rent units) and type of project (new construction, rehabilitation or rehabilitation of a developer-owned property). Developers can raise capital for construction by selling the right to use these credits to investors who want to reduce their federal taxes, attracting private investment to create affordable housing.

Tax credits offset an investor's tax liability dollarfor-dollar. Most investors are individual institutions such as banks, but a syndicator can also help a developer market their credits by combining multiple projects into a single fund, and then offer shares in the fund to individual investors (Keightley 2018).

LIHTC investments are attractive to banks that need to fulfill their Community Reinvestment Act (CRA) obligations. Per the Federal Deposits Insurance Corporation (FDIC) the CRA is a law intended to encourage depository institutions to help meet the credit needs of the communities in which they operate, including low- and moderate-income neighborhoods.

Unlike LIHTC investors, the diverse pool of opportunity zone investors would be comprised of investors with sizeable amounts of capital gains (investment funds, individuals, mutual funds, etc.).

The federal government, through the LIHTC, allocates credits to each state based on their population and gives the state government the authority to administer the credits through state Housing Finance Authorities (HFAs). According to $\S 42(\mathrm{~h})(3)(\mathrm{C})(\mathrm{ii})$ of Revenue Procedure 201857 , the 2019 credit is the greater of $\$ 2.75625$ multiplied by the State population, or $\$ 3,166,875$ (IRS 2018). In contrast, there are no dollar value limits on reinvested capital gains into opportunity zones.

\section{Tax Advantages of Like-Kind Exchanges vs. Opportunity Zone Investments}

Under Section 1031 business owners and investors may exchange like-kind property and defer recognition of the realized gain until it is eventually sold for cash or exchanged for another non-like-kind property. To meet the standard of gain recognition deferral, as amended by the 2017 Tax Cuts and Jobs Act (TCJA), the property transferred and the replacement property must both be real property (not personal). Additionally, the properties transferred and the replacement property must both be used for investment purposes or used in a trade or business (not personal use property) and must be in compliance with certain time restrictions if it is not a simultaneous exchange (i.e. if a thirdparty intermediary is involved, the taxpayer must identify the likekind property to be purchased by the intermediary within 45 days of transferring the property to the intermediary, and the taxpayer must close on the purchase of the replacement property within 180 days of transferring the property to the intermediary). Thus, the 


\section{International Journal of Business and Applied Social Science (IJBASS)}

E-ISSN: 2469-6501

VOL: 6, ISSUE: 4

April/2020

DOI: 10.33642/fjbass.v6n4p8

CPER

https://iibassnet.com/

\section{(C) Center for Promoting Education and Research (CPER) USA}

WWW.cpernet.org

adjusted basis of the replacement property is the exchanged basis of the like-kind property the taxpayer transferred.

Section 1031 is a widely used tax deferral tool benefitted by real estate investors for decades. In contrast, the Investing in Opportunity Act ("The Act") includes much stronger tax incentives for taxpayers with very different kinds of restrictions. The Act does not limit to real property on either side of the transaction. A taxpayer may sell a portfolio of securities and reinvest the gain into an Opportunity Zone Fund that invests in non-real estate Opportunity Zone businesses. Further, the Act provides for permanent tax avoidance of $10 / 15 \%$ of the reinvested gain, as well as permanent tax avoidance of any potential gain generated by the new Opportunity Zone Fund.

\section{Tax Advantages of Like-Kind Exchanges vs. Opportunity Zone Investments}

Under Section 1031(a)(1) of the Internal Revenue Code business owners and investors may exchange like-kind property and defer recognition of the realized gain until it is sold for cash or exchanged for another non-like-kind property. To meet the standard of gain recognition deferral, as amended by the 2017 Tax Cuts and Jobs Act (TCJA), the property relinquished, and the replacement property must both be real property (not personal).

Additionally, both the property transferred and the replacement property must be used for investment purposes or used in a trade or business (not personal use). Finally, as per Section 1031(a)(3), except in the case of a simultaneous exchange, the exchange must meet certain time restrictions; the taxpayer must identify the replacement property with the intermediary within 45 days of the sale of the relinquished property, and the taxpayer must close on the replacement property within 180 days of the sale of the relinquished property. If these requirements are met, Section 1031(d) rules that the adjusted basis of the replacement property is carried over from the relinquished property.

Section 1031 is a widely used tax deferral tool that has been benefitting real estate investors for decades. Investment in Opportunity Zones provides greater tax incentives for taxpayers, but with different restrictions. Sections 1400Z-1 and 1400Z-2 do not require reinvested gains to stem from real property and do not require reinvestment into real property. For example, a taxpayer may sell a portfolio of securities and reinvest the gain into a QOF that invests in the non-real estate QOZ business.

By definition, a like-kind exchange, if it is completely like-kind, requires the complete reinvestment of the amount realized (the replacement property), whereas Section 1400Z-2 provides for tax deferral of capital gains only. Thus, a taxpayer may reinvest all or part of the realized gain, but only the portion of the realized gain that is reinvested into a QOF will be eligible for tax deferral.

The amount that is invested into the QOF more than the realized gain is not eligible for this tax deferral.

Section 1031 allows for gain deferral indefinitely, provided the taxpayer continues to exchange the property in like-kind transactions (even until death, at which point the taxpayer's heirs receive the respective property with a stepped-up basis, as per Section 2031(a)), but should the property ever be transferred in a non-like-kind transaction (i.e. not in compliance with the Section 1031 rules), the taxpayer must recognize the gain at that point.

In contrast, Section 1400Z-1 provides for a tax deferral of gains for 10 years or until December 31, 2026, and potential permanent tax avoidance.

Section 1031 is designed for single-asset transactions, whereas Section 1400Z-2 allows for investment into a QOF that could diversify by purchasing a variety of assets, although limited by location to Qualified Opportunity Zones.

\section{Conclusion}

While the multitude of tax benefits offered by opportunity zone investments is attractive, there are still significant gaps in the regulations. Many questions are left unanswered, such as the impact of a sale of QOF property on partners after the reinvestment of gains or whether there will be a grace period for QOFs that become noncompliant. Future guidance from the Treasury is anticipated.

Further, each opportunity needs to be deeply scrutinized among other concerns, an investor should understand the property, the developer, the logistics of the project, and the expected return. It is also important to assess whether the state adheres to the federal tax position on opportunity zones. Investors must be cognizant of the risks and caveats involved in real estate development and be mindful of their liquidity needs as opportunity zone investing requires long term investment to enjoy the tax benefits

\section{References}

Bertoni, Steven. 2018. "An Unlikely Group of Billionaires and Politicians Has Created the Most Unbelievable Tax Break Ever". Forbes. Accessed January 8, 2019. https://www.forbes.com/sites/forbesdigitalcovers/2018/07/17/an-unlikelygroup-of-billionaires-and-politicians-has-created-the-most-unbelievable-tax-break-ever/\#40b23c6a1485

Cornell Law School Legal Information Institute. n.d. "26 U.S. Code $§ 1031$. Exchange of real property held for productive use or investment.” Accessed February 5, 2019. https://www.law.cornell.edu/uscode/text/26/1031 
Cornell Law School Legal Information Institute. n.d "26 U.S. Code $\S 2031$. Definition of gross estate.” Accessed February 5, 2019. https://www.law.cornell.edu/uscode/text/26/2031

Economic Innovation Group. 2018. “Opportunity Zones: Tapping into a \$6 Trillion Market”. Accessed January 9, 2019: https://eig.org/news/opportunity-zones-tapping-6-trillion-market

Federal Deposit Insurance Corporation. Division of Depositor and Consumer Protection. "Community Reinvestment Act”. Accessed on 1/26/2019. https://www.fdic.gov/regulations/resources/director/presentations/cra.pdf

Fundrise Opportunity Fund. N.d. "Opportunity Fund or 1031 Exchange: Which Offers Better Tax Advantages for Real Estate Investors?” Accessed February 5, 2019. https://fundrise.com/education/blog-posts/opportunity-fund-1031exchange-tax-advantages-for-real-estate-investors

Keightley, M. 2018. "An Introduction to the Low-Income Housing Tax Credit". Congressional Research Service. Accessed on January 25, 2019. https://fas.org/sgp/crs/misc/RS22389.pdf

United States Congress. "Investing in Opportunity Act of 2017”. S. 293, 26 U.S.C. §1400Z-1, §1400Z-2. Accessed on January 7, 2018. https://www.congress.gov/bill/115th-congress/senate-bill/293

United States Department of the Treasury. Internal Revenue Service. 2018. "Revenue Ruling 2018-29: Section 1400Z-2Special Rules for Capital Gains Invested in Opportunity Zones”. Accessed on January 9, 2019. https://www.irs.gov/pub/irs-drop/rr18-29.pdf

United States Department of the Treasury. Internal Revenue Service. 2018. "Internal Revenue Bulletin 2018-28". Accessed January 10, 2019. https://www.irs.gov/pub/irs-irbs/irb18-28.pdf

United States Department of the Treasury. Office of Public Affairs. 2018. "Treasury Releases Proposed Regulations on Opportunity Zones Designed to Incentivize Investments in American Communities". Accessed on January 12, 2019: https://home.treasury.gov/news/press-releases/sm530

United States Department of the Treasury. Internal Revenue Service. 2018. 26 CFR Part I [REG-115420-18]. Accessed on January 12, 2018. https://www.irs.gov/pub/irs-drop/reg-115420-18.pdf

United States Department of the Treasury. Internal Revenue Service. 1996. "Enterprise Zone Facility Bonds" Accessed on January 12, 2019. https://www.irs.gov/pub/irs-regs/td8673.txt

United States Department of the Treasury. Internal Revenue Service. 2018. "Tax Tip 2018 - 191: Tax Reform Provides Opportunity Zone Tax Incentive". Accessed on January 16, 2019. https://www.irs.gov/newsroom/tax-reformcreates-opportunity-zone-tax-incentive

United States Department of the Treasury. Internal Revenue Service. 2018. “Instructions for Form 8996”. Accessed on January 16, 2019. https://www.irs.gov/pub/irs-dft/i8996--dft.pdf

United States Department of the Treasury. Internal Revenue Service. 2018. "Internal Revenue Bulletin 2018-28". Accessed on January 27, 2019: https://www.irs.gov/pub/irs-irbs/irb18-28.pdf

United States Department of the Treasury. Internal Revenue Service. 2018. "Revenue Procedure 2018-57". Accessed on January 28, 2019. https://www.ncsha.org/wp-content/uploads/2018/11/rp-18-57.pdf 